\title{
Electronic (Digital) Educational Resource as a Tool of Teaching a Foreign Language in the System of Higher Education
}

\author{
Salimzanova D.A. \\ Naberezhnye Chelny Institute of Kazan (Volga) Federal \\ University, Russia \\ gilfanova_di@list.ru
}

\author{
Gilfanova G.T. \\ Naberezhnye Chelny Institute of Kazan (Volga) Federal \\ University, Russia
}

\begin{abstract}
The article discusses the possibilities of using electronic content, as well as the structure of an electronic educational resource in teaching a foreign language in the universities. The ability to speak foreign languages fluently and apply them in professional activities is undoubtedly the quality of a competent specialist in the economic sphere. The aim of the study is to consider the necessity of introducing digital (textual), visual, audio and video materials, ensuring the effectiveness of foreign language being learned by students. Using the didactic and managerial capabilities of electronic educational resources, students get free access to the worldwide network not only for deep mastery of foreign language speech but also for using the basics of Internet technologies. This determines the relevance of this article. Our research was based on theoretical (modeling method) and empirical methods (methods of control, measurement and data processing). Result: digitalization of educational material (ESM) contributes to the formation of learners' foreign speech skills, materials, ensuring the effectiveness of the foreign language learning process.
\end{abstract}

Keywords: informatization of the university educational process, electronic educational resources, foreign language, information and communication technologies, economic sphere

\section{INTRODUCTION}

Over the past few decades, information and communication technologies have been key factors in the development of modern society. Employers today have ambiguous requirements for the potential employees, and fluency in using Internet technologies, the ability to find, extract and analyze necessary information from various electronic sources, communication and interaction skills in a virtual environment are becoming one of the main selection criteria. The task to develop these skills at the professional level is provided by the competencies that are formed in the process of receiving higher education. The successful use of the electronic environment in the context of the modernization of education in accordance with the work programs of the disciplines of the third generation of the Federal State Educational Standards (FSES) creates prerequisites for selforganized and self-regulated learning.

In modern information-laden society, when knowledge truly becomes a force, it is difficult for students not to get lost in the huge flow of information that they need to master in various disciplines and the teacher's task now is to guide the student to the "right direction" and help him organize his learning activities. An effective tool in the hands of a teacher is becoming an e-learning system (ELS), designed to improve the quality of education through competent planning of the academic load, management of educational materials and quality control of knowledge. Management of educational materials is carried out only in the presence of educational and methodological support or, in other words, electronic educational resources (EER), which include electronic copies of printed publications, electronic interactive textbooks, multimedia presentations of educational material, computer testing systems, survey lectures on audio and video carriers, computer simulators, virtual laboratories, intelligent training systems, training packages of application programs, etc. [1].

\section{RESEARCH METHODS}

Since one of the priority tasks of language training in higher education is the formation of the information and communication competence of graduates, which is the basic characteristic of specialists regardless of the specifics of their professional activity, its solution should be carried out comprehensively and systematically in the following areas: 1 . Informatization of the educational process through the development and introducing of e-learning resources into foreign language teaching;2. Equipping of high school research laboratories with modern software and technical tools for informatization; 3. Informatization of the university management system. It should be noted that the first direction is for teachers of foreign languages of the area in which their 
pedagogical skills and the desire to use innovative teaching tools based on modern information technologies are maximally realized [2, 3, 4], since the introduction of electronic educational resources leads to a significant change in both student learning and teaching. Thus, the form of interaction between the teacher and the student is changing: the electronic educational resource becomes the "quasisubject" of the pedagogical system, which makes it possible to individualize the process of learning a foreign language and provide an individual trajectory for studying educational material; -the content of educational material in electronic educational resources, as a rule, is presented in educational information modules, the assimilation of which is carried out in accordance with the educational objectives and the selfexamination of the level of mastery of educational material in a foreign language being studied; -students independently work with an electronic educational resource, and they develop self-management skills, including self-planning, selforganization, self-control and self-assessment of their learning activities.[5].

In the methodological and technological implementation of electronic educational resources in teaching a foreign language it is necessary to take into account their didactic and managerial capabilities. In the methodological construction of a modular structure of electronic educational resources in order to provide information support for students' educational activities both in class and in independent work, it is necessary to provide modules for goal-setting, organization and submission of educational content, as well as modules for controlling materials. In addition, management modules should be included to analyze the results of self-examination of students' knowledge of a foreign language, which will allow both teachers and students to monitor the success of studying educational material in dynamics [6]. Methodological and technological basis for the development of electronic educational resources in teaching a foreign language is the use of multimedia technology and hypertext technology, which provide great opportunities for submitting educational content in an interactive form using nonlinear organization of text material, the ability to create cross-references in text arrays, which facilitates the search for the desired information by keywords.

Hypermedia systems allow you to connect not only text fragments, but also graphics, digitized speech, sound recordings, photographs, cartoons, video clips [7]. In the technological implementation of electronic educational resources in teaching a foreign language developers choose a method that involves using authoring systems that allow a teacher-developer to enter his or her educational material into a database and program using special authoring languages or other means to learn it or the method of "direct programming" that is so-called "island" information. The method of "direct programming" assumes for the development of an electronic educational resource the creation of a creative team that implements the entire didactic and technological cycle of their creation, including testing in the educational process.

\section{RESUlTS}

The use of an electronic educational resource is one of the most relevant and attractive forms of organizing a foreign language study that makes the learning process more effective, exciting and affordable. When properly used, electronic content of this kind can act as a tool for the formation of various professional and general cultural competences for two reasons.

First, the material of electronic educational resource and its presentation should contribute to the formation of skills and abilities to work in the information space, independent search, evaluation, selection, analysis and interpretation of information. Secondly, video and audio material, graphics, hyperlinks for entering the Internet space significantly expands the students' horizons, enriches their general scientific knowledge and promotes professional self-determination.

Electronic educational resources include metadata for the exact discipline and the following set of components for each module topic: 1) guidelines for students and teachers; 2) glossary; 3) literature and references; 4) control unit; 5) open electronic resources; 6) educational and practical material containing worksheets with varied lexical and grammatical exercises on the topic (Arbeitsblätter), audio and video materials (educational videos in the original language), tables and presentations (Power Point) for an easy explanation of the material on the topic and its correction. Lexical tasks in the electronic environment serve as a means of enriching students' vocabulary and activating it by working with thematic vocabulary. The study of grammatical structures is carried out in a new way to Oshontekst, for example, using interactive grammar tables. It is also necessary to note the possibility of intensive listening skills training based on authentic audio materials taken from the Internet (for example, using the popular YouTube channel).

The advantages of using electronic educational resources in teaching a foreign language are obvious. A wide choice of various courses, multimedia products and manuals only confirms this view. However, it should be noted that language university teachers face the problem of selecting similar materials for teaching a second foreign language to foreign students enrolled in the field of «Translation and Translation Studies». The arising difficulties force them to develop copyright electronic educational resources taking into account the specifics of the educational program and the requirements for students.

\section{DISCUSSION}

Let us consider as an example the structure of an electronic educational resource for the development of oral communication skills on the basis of viewed videos in German for students of the "Translation and Translation Studies" field of study, developed by teachers of the Department of Philology, primarily intended for the development of listening and speaking skills on the basis of watching video materials on humanitarian and country studies topics. The specifics of empirical research on the stated topic is the fact that the developed digital tasks were tested in the classroom with foreign students. 


\section{CONCLUSIONS}

The authors adhere to a modular system for organizing an educational resource. The themes of the modules are determined by the focus of the work program on the discipline "Practical Course of a Second Foreign Language" and each module consists of several sections, including an active dictionary for repetition ("Educational and Practical Material"). These sections cover a set of tasks intended for familiarization, development and productive use of educational material at different stages of implementation.

In addition to the electronic educational resource, there can be used computer programs to automate the control and evaluation of knowledge of grammar and vocabulary. For this purpose, classrooms are equipped with the Sanako Study 1200 multimedia software system. Thanks to the joint work of programmers and teachers of foreign languages it became possible to use in the learning process tests with the ability to record, write notes, paste copied text from a textbook, fill in parts of the missing text or missing symbols, numbers, formulas [8].

Before listening to a sound recording, foreign students are selected in the task system to understand the material, in order to focus on discussion in pairs and groups. For this the Sanako 1200 has a "round table" mode, which allows the teacher to create small groups with a designated chairperson leading the discussion.

Before the start of watching videos students are invited to answer introductory questions in order to activate background knowledge and clarify their attitude to the module topic; work out the most difficult phonetic material; perform tasks aimed at expanding vocabulary and the development of skills in the use of general scientific vocabulary and terms. Watching video is accompanied by various exercises that involve extracting basic information, understanding the structure and organization of the video content; working out the main lexical material with special attention being paid to stable combinations of words, phraseological turnovers, phrasal verbs and basic theoretical terminology. In addition, students perform assignments aimed at summarizing the material reviewed in the form of a brief oral presentation. Thus, the skills of productive oral communication in a foreign language are practiced.

The structure of the electronic material provides a glossary, which contains additional material of an informative nature, in particular foreign-language geographic, cultural and historical realities. Finally, students are offered a list of words in a downloadable file in the Microsoft Office Word format, which contains 20 basic lexical units in the original language to memorize.

The electronic digital resource also contains a "Reference Material" section, in which theoretical information is presented, practical recommendations for performing the module's tasks are provided and authentic videos which are uploaded on YouTube's video channel and student websites. As a result, through digital material, foreign students overcome language difficulties, perceive foreign language speech and begin to speak in the following pattern: native speaker speech is the native language.
1. The use of electronic educational resources contributes to the improvement of the educational process, more effective mastering of foreign language by students, which is carried out at a more productive and conscious level.

2. Electronic educational resources combine the benefits of traditional and innovative approaches. Modern forms of the submission of language material, its refinement and verification of learning form the habit of independent learning, planning an individual educational trajectory and, as a consequence, continuing education.

3. The introduction of electronic educational content optimizes and facilitates the learning process, leading students to the independent solution of learning tasks and the acquisition of knowledge.

4. The study revealed that the electronic educational resource is an effective tool in language training in the modern academic university process, and the most preferred method is the direct programming method that provides developers with the full realization of all the didactic and managerial capabilities of electronic educational resources: interactivity, multimedia presentation of educational content, modeling of real objects and processes, communication, formation of an individual trajectory of a student, accessibility of educational resources through global computer networks. The facts discussed above are especially important for the higher education system because almost two thirds of the student community are foreign students (near and far abroad), who experience great difficulties not only in communication in Russian, but in learning foreign languages, especially if it is their second foreign language.

\section{REFERENCES}

[1] A. Solovov, "E`lektronnoe obuchenie - novaya tekhnologiya ili novaya paradigma?", Distanczionnoe i virtual noe obuchenie, 2007, no. 3, pp. 58-61.

[2] A. V. Antonova and N. M. Vishtak, "Informaczionny`e tekhnologii kak bazovy`j komponent innovaczij v obrazovanii", Prepodavatel`skii vek, 2010, T. 1 , no. 3, pp. 22-25.

[3] O. V. Vishtak, "Napravleniya programmnoj realizaczii e`lektronny`kh obrazovatel`ny`kh resursov", Sbornik nauchny`kh trudov S World, Odessa: KUPRIENKO, 2013, vol. 2, T. 5, pp. 36-39.

[4] N. E. Esenina, "Ispol`zovanie e`lektronny`kh spravochnoinformaczionny`kh sistem $\mathrm{v}$ obuchenii professional’no orientirovannomu inostrannomu yazy`ku", Vy`sshee obrazovanie segodnya, 2012, vol. 3, pp. 65-69.

[5] D. L. Matukhin, "Metodologicheskie osnovy' smeshannoj formy` obucheniya professional`nomu inostrannomu yazy`ku studentov tekhnicheskikh speczial nostej", Sovremenny`e problemy` nauki i obrazovaniya, 2014, no. 2, 273 p.

[6] D. V. Kondratov, "Razvitie svobodnogo programmnogo obespecheniya v Rossijskoj Federaczii", Sistema podgotovki upravlencheskikh kadrov v Rossijskoj Federaczii v usloviyakh modernizaczii: sb. nauchn. trudov, Saratov: Povolzhskij institut upravleniya im. P. A. Stoly`pina, 2012, pp. 163-164.

[7] L. I. Asadullina and A. V. Didenko, "Sredstva e`lektronnoj kommunikaczii v obuchenii inostrannomu yazy`ku", Filologicheskie nauki, Voprosy` teorii i praktiki, 2010, no. 1-2, pp. 14-17. 
e'ksperimental'nogo obrazovaniya, M., 2016, vol. 6; part 2, pp. 211213.

[17] M. Prensky, "From Digital Natives to Digital Wisdom: Hopeful Essays to 21st Century Learning", Corwin Press, 2012 [Electronic resource]. Available at: http:// marcprensky.com/from-digital-natives-to-digitalwisdom.

[18] S. Ravizza, D. Hambrick, and K. Fenn, "Non-academic Internet use in the Classroom is negatively related to Classroom Learning Regardless of Intellectual Ability: Computers \& Education", 2014, 10 (4), pp. 109114.

[19] Y. Shaoo, "Second Language Learning by Exchanging Cultural Contexts through the Mobile Group Blog" [Electronic resource]. Available at: https://docviewer.yandex.ru (Accessed: 14 April 2019).

[20] E. N. Voronova, "Modern technologies and methods of teaching a foreign language in a university", Perspectives of science and education, 2014, no. 1, pp. 189-194.

[21] M. Akbar, "Digital Technology Shaping Teaching Practices in Higher Education", Frontiers in ICT, Digital Education, online journal, 2016 [Electronic resource]

DOI: https://doi.org/10.3389/fict.2016.00001.

[22] P. Greenfield, "Mind and Media: the Effects of Television, Video Games and Computers", Harvard University Press, 1984 [Electronic resource]. Available http://www.cdmc.ucla.edu/Mind_and_Media_files /MMCHP1.pdf.

[23] E. Horvitz, "Disruption and Recovery of Computing Tasks" [Electronic resource]. Available at: http://research.microsoft.com/enus/um/people/horvitz/chi_2007_iqbal_horvitz.pdf

[24] Q. Jones, G. Ravid, and S. Rafaeli, "Information Overload and The Message Dynamics of Online Interaction Spaces: A Theoretical Model and Empirical Exploration", Information System Research, 2004, 15 (2), pp. 194-210. 